\title{
Influence of basic density and temperature on mechanical properties perpendicular to grain of ten wood tropical species
}

\author{
Sandrine Bardet ${ }^{\mathrm{a} *}$, Jacques Beauchêne ${ }^{\mathrm{b}}$ and Bernard Thibaut ${ }^{\mathrm{a}, \mathrm{c}}$ \\ a Laboratoire de Mécanique et de Génie Civil, Équipe Bois, CC 048, Université Montpellier II, Place E. Bataillon, \\ 34095 Montpellier Cedex 5, France \\ b CIRAD Forêt, BP 701, 97387 Kourou Cedex, Guyane, France \\ c CIRAD Forêt, 73 rue JF Breton, TA 10/16, 34398 Montpellier Cedex 5, France
}

(Received 17 August 2001; accepted 10 October 2001)

\begin{abstract}
The influence of temperature on transverse mechanical properties of 10 tropical species in green condition was studied in radial compression $\left(0\right.$ to $\left.99^{\circ} \mathrm{C}\right)$, transverse shear with longitudinal-radial shearing plane and rupture of the longitudinal-tangential plane $\left(20\right.$ to $\left.80{ }^{\circ} \mathrm{C}\right)$. Basic density ranged from 0.21 to $0.91 \mathrm{~g} \mathrm{~cm}^{-3}$. Load-displacement curves were characterised by initial rigidity, yield stress, yield strain and strain energy at $20 \%$ strain level. The relation between each criterion and basic density was expressed by a power law. The dependency on temperature evidenced a sharp glassy transition, except for the fracture energy only slightly influenced by temperature. An empirical model allowed evaluating a transition temperature between 51 and $69^{\circ} \mathrm{C}$, depending on the species and the criterion, which was attributed to lignin. Detailed analysis of the apparent modulus in radial compression suggested that complex relaxation phenomena occur around $10^{\circ} \mathrm{C}$ and that the rubbery state is not fully reached at $80{ }^{\circ} \mathrm{C}$.
\end{abstract}

green wood / tropical wood / transverse mechanical properties / basic density / softening temperature

Résumé - Influence de l'infradensité et de la température sur les propriétés mécaniques transverses de dix bois tropicaux. L'influence de la température sur les propriétés mécaniques transverses du bois vert de 10 essences tropicales a été étudiée. Trois types d'essais ont été réalisés : compression radiale (entre 0 et $99^{\circ} \mathrm{C}$ ), cisaillement transverse suivant le plan longitudinal-radial et rupture dans le plan longitudinaltangentiel (entre 20 et $80^{\circ} \mathrm{C}$ ). L'infradensité des essences est comprise entre 0,21 et $0,91 \mathrm{~g} \mathrm{~cm}^{-3}$. Les courbes force-déplacement ont été caractérisées par la rigidité initiale, la contrainte de flambement, la déformation de flambement et l'énergie de déformation pour $20 \%$ de déformation. La relation entre chaque critère et l'infradensité est exprimée par une loi puissance. La dépendance des critères avec la température met en évidence une transition vitreuse très prononcée, excepté pour l'énergie de rupture peu influencée par la température. Un modèle empirique permet d'évaluer une température de transition entre 51 et $69^{\circ} \mathrm{C}$, selon les essences et les critères. Ce phénomène est expliqué par la transition vitreuse des lignines. Une analyse détaillée du module radial apparent en compression suggère qu'un phénomène de relaxation complexe a lieu autour de $10^{\circ} \mathrm{C}$ et que l'état caoutchoutique n'est pas complètement atteint à $80^{\circ} \mathrm{C}$.

bois vert / essences tropicales / propriétés mécaniques transverses / infradensité / température de transition vitreuse

\section{INTRODUCTION}

Improvement of basic knowledge on mechanical properties of tropical woods is of prime importance for the development of wood industry in French Guyana. Peeling and machining ability is usually correlated to basic density of woods [7]. Nevertheless, it seems that a detailed study of mechanical behaviour of green wood is prevailing to determine peeling and machining ability [10]. In particular, influence of temperature has to be taken into consideration $[1,8]$.

Veneer formation during slicing or rotary cutting is accompanied by a complex combination of radial compression, transverse shear and transverse splitting. Each of these mechanical actions is strongly depending on the steaming temperature applied to the log. Their simulation requires an improved knowledge of green wood rheology transversally to the fibres and it is of prime importance to understand the influence of temperature on each mechanical phenomenon. Moreover, experimental results about the effect of temperature on mechanical properties of wet wood provide important data for wood rheology, regardless of peeling and machining applications.

The complex behaviour of wood is related to its composite nature. Wood can be regarded as a superposition of an amorphous matrix composed of both lignin and hemicelluloses and a reinforcement of semi-crystalline fibres composed of cellulose.

* Correspondence and reprints

Tel.: 04671449 18; fax: 04671447 92; e-mail: bardet@1mgc.univ-montp2.fr 
Table I. Names and basic density of the species studied; names in bold will be used afterwards.

\begin{tabular}{|c|c|c|c|c|c|}
\hline Scientific name & Local name & $\begin{array}{c}\text { Density at } 12 \% \\
\mathrm{mc}\left(\mathrm{g} \mathrm{cm}^{-3}\right)\end{array}$ & $\begin{array}{l}\text { Standard } \\
\text { deviation }\end{array}$ & $\begin{array}{c}\text { Basic density } \\
\left(\mathrm{g} \mathrm{cm}^{-3}\right)\end{array}$ & $\begin{array}{l}\text { Standard } \\
\text { deviation }\end{array}$ \\
\hline Parkia sp. & Dodomissinga & 0.271 & \pm 0.035 & 0.212 & \pm 0.015 \\
\hline Virola surinamensis A.C. Smith & Yamamadou marécage & 0.453 & \pm 0.010 & 0.345 & \pm 0.008 \\
\hline Vochysia sp. & Moutende Kouali & 0.674 & \pm 0.011 & 0.500 & \pm 0.017 \\
\hline Ocotea rubra Mez. & Grignon blanc & 0.732 & \pm 0.045 & 0.590 & \pm 0.025 \\
\hline Humiria balsamifera (Aublet) St Hil. & Bois rouge & 0.818 & \pm 0.037 & 0.581 & \pm 0.028 \\
\hline Dicorynia guianensis Amsh. & Angélique & 0.770 & \pm 0.018 & 0.620 & \pm 0.016 \\
\hline Humenolobium sp. & Saint-Martin jaune & 0.752 & \pm 0.031 & 0.650 & \pm 0.017 \\
\hline Vouacapoua americana Aubl. & Wacapou & 0.935 & \pm 0.031 & 0.773 & \pm 0.030 \\
\hline Tabebuia cf. capitala Sandw & Ebène verte & 1.066 & \pm 0.013 & 0.889 & \pm 0.017 \\
\hline Bocoa prouacensis Aubl & Boco & 1.178 & \pm 0.033 & 0.909 & \pm 0.006 \\
\hline
\end{tabular}

Globally, mechanical properties of wood may be affected by glassy transition of each amorphous component, which is in turn influenced by temperature, moisture content and time scale of experiment. So experimental conditions are of prime importance to analyse the transitions observed.

In the present paper, mechanical tests perpendicular to grain on tropical species at different temperatures varying over a span of 0 to $99{ }^{\circ} \mathrm{C}$ are presented [2]. The samples were saturated with water, so moisture content can be considered as a fixed parameter. Various mechanical effects (stiffness, strength, deformation and energetic criteria) are chosen to describe load displacement curves from these tests. Evolution of each criterion is analysed respect to basic density and temperature.

\section{MATERIALS AND METHODS}

\subsection{Testing machine and thermal regulation}

Mechanical tests were performed on a universal testing machine (Classic of Wykeham Farrance England), on which three different load cells could be installed with capacity of $50 \mathrm{kN}, 5 \mathrm{kN}$ and $2 \mathrm{kN}$. Strain measurements were obtained using two displacement sensors (LVDT transducers) placed between the upper fixed platen and the moving one, the displacement being calculated as the average of both variations. Specimens and testing system were placed into a water bath controlled at constant temperature to within $0.1^{\circ} \mathrm{C}$ using an electrical heating. To avoid a thermal drift of the load cell, an insulation system was installed.

It should be pointed out that we measured an apparent strain that is a superposition of the real strain of specimens and the elastic deformation of the frame, so we are dealing with apparent moduli.

\subsection{Preparation of specimens for mechanical tests}

Specimen were cut from tropical wood logs in the orthotropic directions, then placed in a vacuum cell for 30 minutes to fully saturate the wood, and kept soaked in water. Just before mechanical testing, the specimens with the shape of cubes were heated in water to the bath temperature in order to minimise the time needed to reach thermal equilibrium. Table I gives names, density at $12 \%$ wood moisture content and basic density of the Amazonian species used. Basic density is calculated as dried weight divided by saturated volume.

\subsection{Compression tests}

Compression test device is described in figure 1a, in which the $50 \mathrm{kN}$ load cell is used. Samples were $30 \mathrm{~mm}$ width cubes. Specimen from ten different species were compressed in the radial direction to

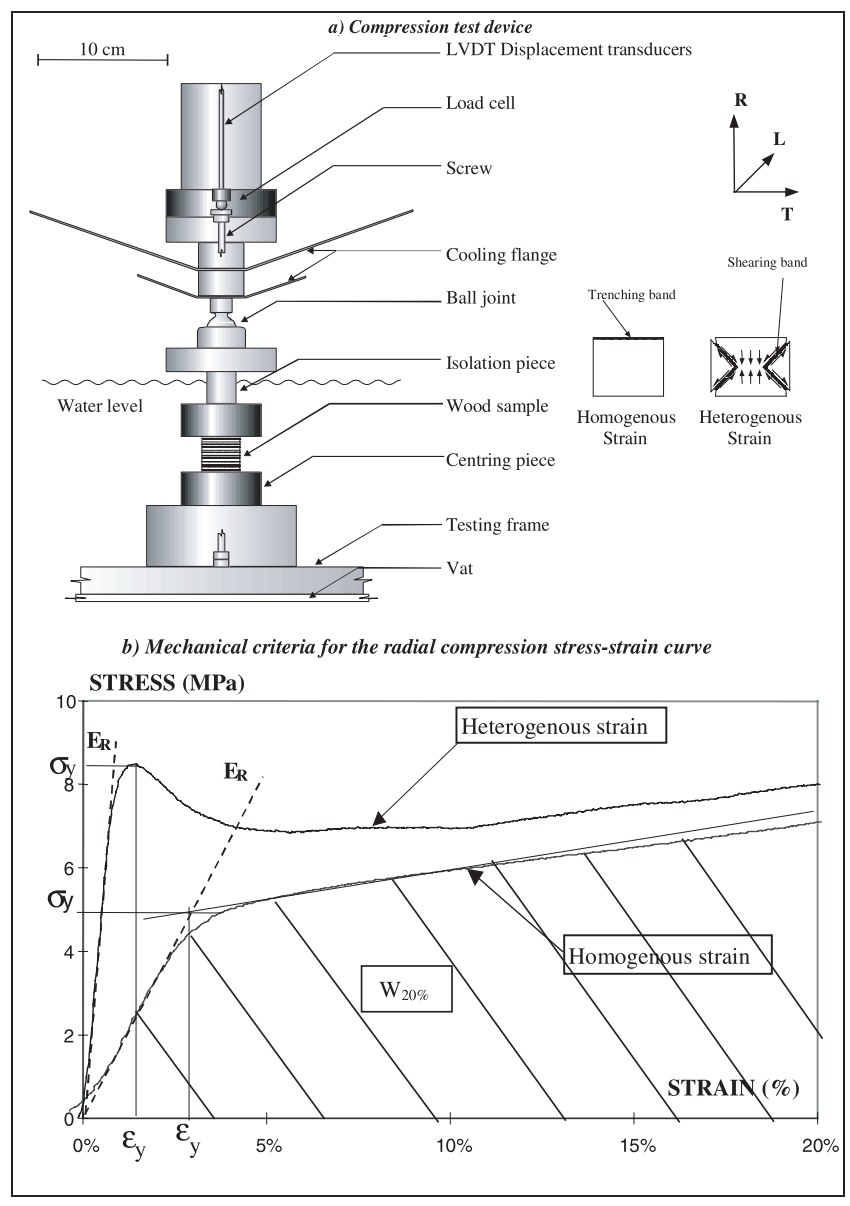

Figure 1. Radial compression tests: (a) compression tests apparatus; (b) radial compression stress-strain curves.

about $23 \%$ of their initial thickness over a temperature range of 0 to $99{ }^{\circ} \mathrm{C}$ at intervals of $5{ }^{\circ} \mathrm{C}$. The displacement rate was $0.5 \mathrm{~mm} \mathrm{~m}{ }^{-1}$, corresponding to a strain rate of $28 \times 10^{-5} \mathrm{~s}^{-1}$. Each test at one temperature for each wood species was repeated 3 times using 3 specimens cut from the same log.

Strain is calculated as displacement divided by initial height ( $\mathrm{R}$ direction) of the sample; stress is calculated as load divided by samples surface perpendicular to loading direction (TL plane). R, T, L refer to the radial, tangential and longitudinal directions, respectively. 


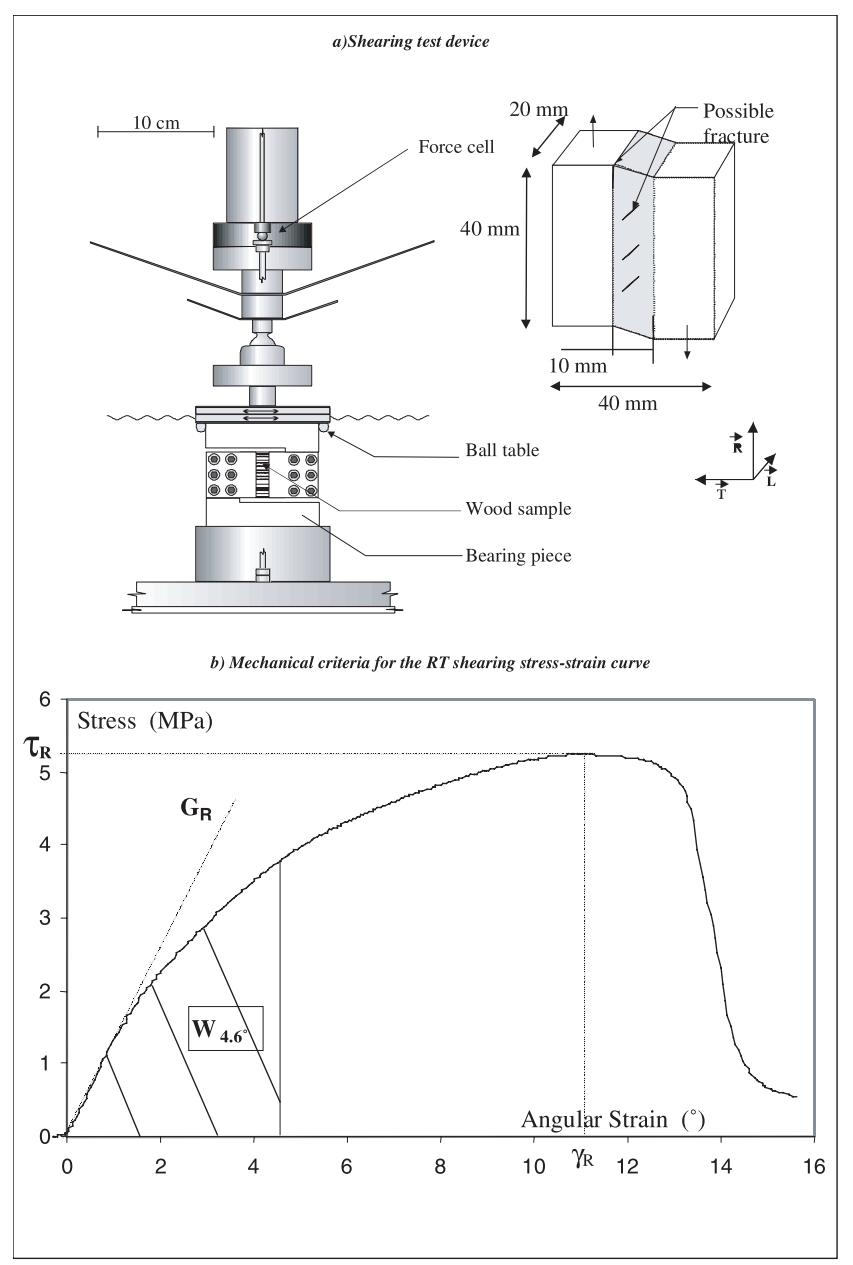

Figure 2. Rolling shear tests: (a) rolling shear tests apparatus; (b) RT shearing stress-strain curve.

The stress-strain curves (figure $1 b$ ) obtained for a homogeneous strain first show a linear regime which is related to the elastic bending of the cell wall. This linear part is followed by a plateau of roughly constant load that is ascribed to the development of cell wall buckling. Finally, the load increases rapidly. It should be noticed that a second type of strain-stress curves exists when strain is heterogeneous. In this case shear bands occur and yield a fall of the load before the plateau.

Four criteria are used to describe load-displacement curves:

- one stiffness criterion, $E_{R}$, which is the slope of the initial linear part of the curve; this parameter can be defined as an apparent radial stiffness;

- one strength criterion, named yield stress $\left(\sigma_{y}\right)$, which is defined as the maximum stress before the crushing zone (heterogeneous strain) or the stress at the intersection between the linear approximation of the plateau and the first linear part (homogeneous test), where $\varepsilon_{\mathrm{y}}$ is the associated deformation;

- one energetic criterion, $\mathrm{W}_{20 \%}$, derived from the area below the curve until $20 \%$ deformation of the sample.

\subsection{Rolling shear tests}

Shearing tests were performed over a temperature range of $25^{\circ} \mathrm{C}$ to $80^{\circ} \mathrm{C}$ at intervals of $5{ }^{\circ} \mathrm{C}$. Test device is shown in figure $2 a$, in which the $5 \mathrm{kN}$ load cell is used.

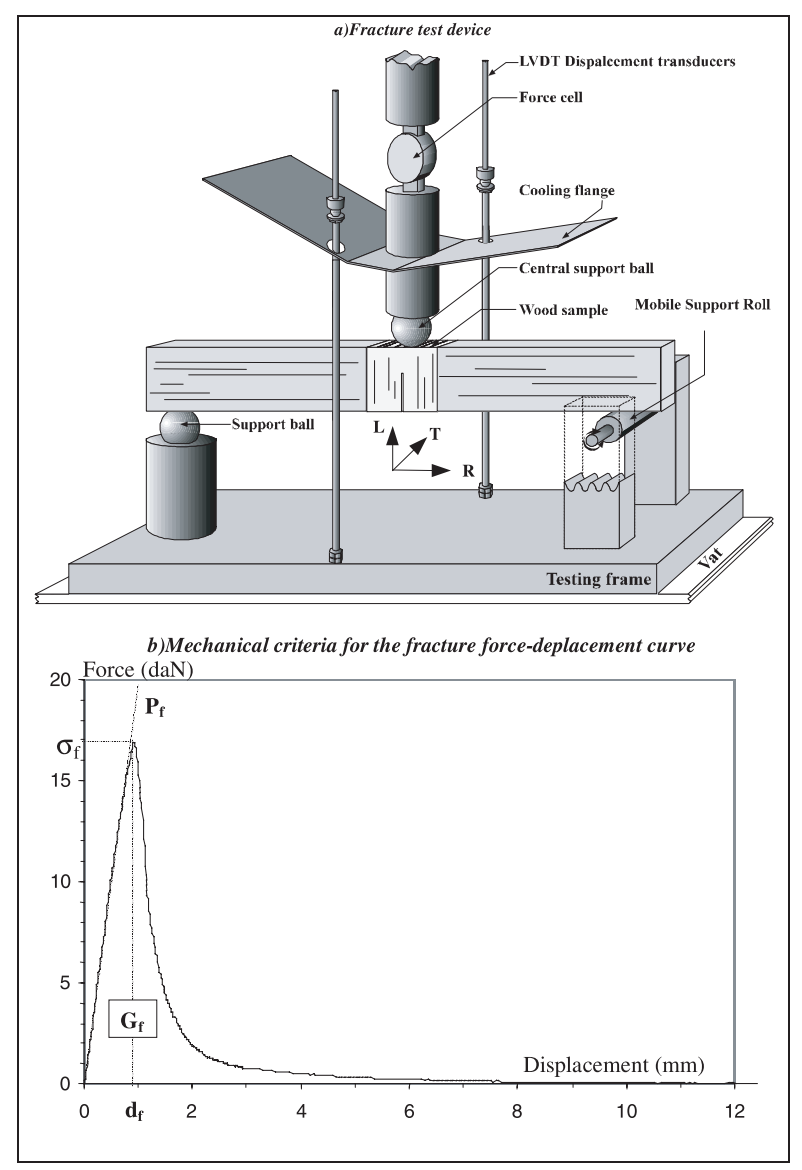

Figure 3. Fracture toughness tests: (a) fracture test apparatus; (b) fracture force-displacement curve.

Samples dimensions were $20 \mathrm{~mm}$ in the longitudinal direction, $40 \mathrm{~mm}$ in the radial and $40 \mathrm{~mm}$ in the tangential one. The sample was clamped between rugged metal plates allowing the deformation of a $40 \times 10 \mathrm{~mm}^{2}$ central zone in a parallelogram shape. The shearing plane was RL, the loading rate was $0.5 \mathrm{~mm} \mathrm{~m}^{-1}$, corresponding to a strain rate of $5 \times 10^{-3} \mathrm{~s}^{-1}$. The maximum shearing angle was $16.7^{\circ}$. Insofar as it is not a proper shearing test leading to a correct shearing modulus, we have to do with apparent radial shearing modulus $G_{R}$. Shearing angle is calculated as inverse tangent of displacement divided by $10 \mathrm{~mm}$ (T dimension of the shearing zone). Stress is calculated as load divided by $40 \times 20 \mathrm{~mm}^{2}$ (RL plane of the shearing zone).

Referring to the curve of stress against shearing angle (figure $2 b$ ), four criteria can be defined. $G_{R}$ the stiffness criterion, is calculated as the slope of the first linear part. The strength criterion $\left(\tau_{R}\right)$, derived from the maximum load value, $\gamma_{R}$ is the associated angular deformation. An energetic criterion $\left(\mathrm{W}_{4.6^{\circ}}\right)$ is calculated from the area below the curve until a global angular deformation of $4.6^{\circ}$.

\subsection{Fracture toughness tests}

The tenacity test as proposed by Gustafssonn [6] is a three points bending test of a pre-notched sample called SENB (Single Edge Notched specimen in Bending). Samples dimensions were $40 \mathrm{~mm}$ in the longitudinal direction, $40 \mathrm{~mm}$ in the radial and $24 \mathrm{~mm}$ in the tangential. Temperature was varying from $25^{\circ} \mathrm{C}$ to $80{ }^{\circ} \mathrm{C}$ at intervals of 


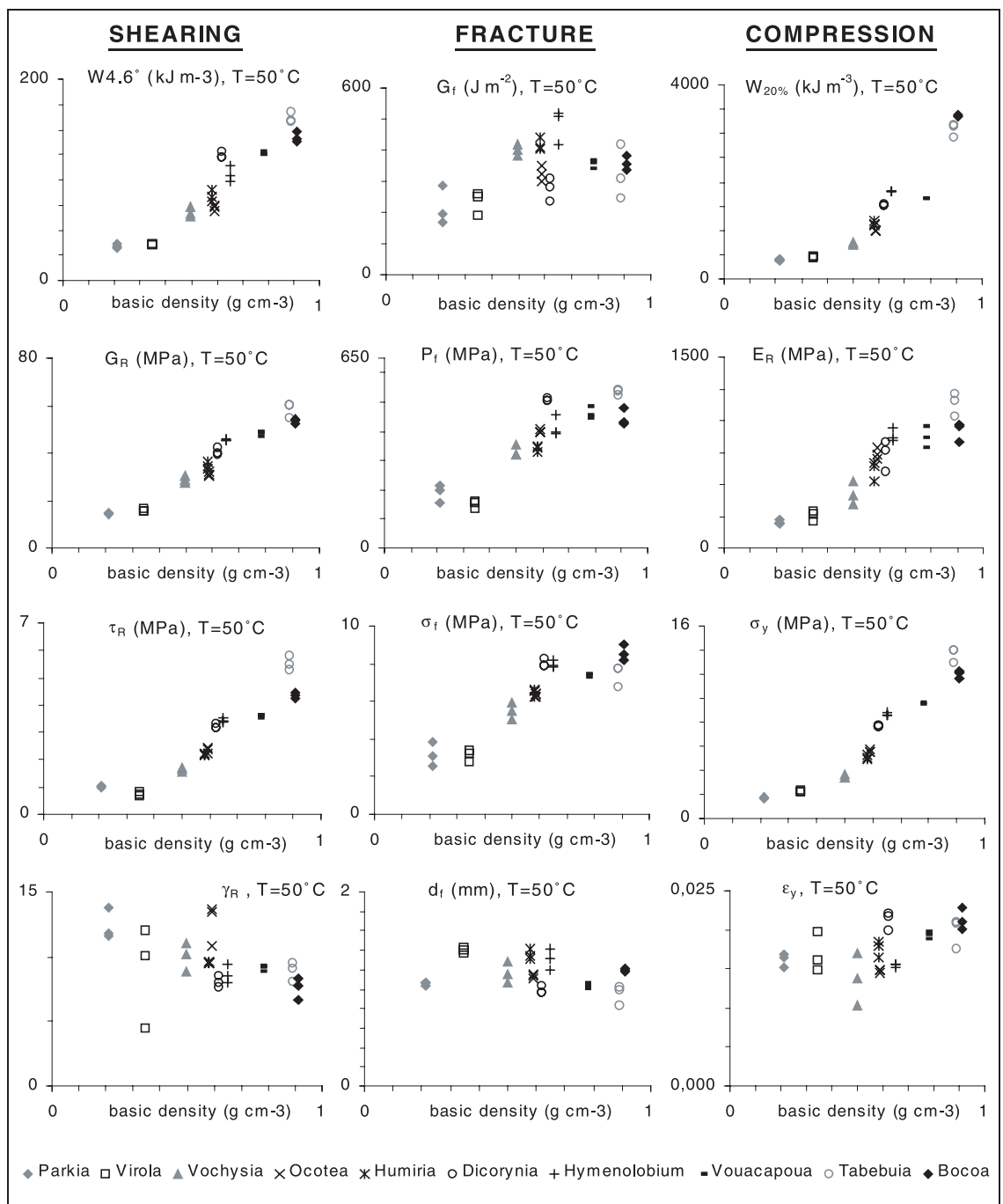

Figure 4. Evolution of mechanical criteria from radial compression test, shearing test and fracture test respect to basic density for $\mathrm{T}=50{ }^{\circ} \mathrm{C}$.

$5{ }^{\circ} \mathrm{C}$. Wet samples were glued to side arms made of Diplotropis purpurea (high density guyanese wood) using a special glue for wet wood SUMITAK 242A from Daiichi Kogyo Seiyaku, Japan, obtained through the courtesy of Pr. Kawai from Kyoto University. The initial crack of $24 \mathrm{~mm}$ long in the $\mathrm{L}$ direction was performed by sawing. Figure $3 a$ illustrates this fracture test, when the $2 \mathrm{kN}$ load cell was used. The rupture occurs is the longitudinal-tangential plane. Displacement rate was $0.3 \mathrm{~mm} \mathrm{~m}^{-1}$ until displacement reaches $3 \mathrm{~mm}$, then the displacement rate was set to $2 \mathrm{~mm} \mathrm{mn}^{-1}$.

Stress and strain are calculated as if it was a beam tested in three points flexion with a section of $16(\mathrm{R}) \times 24(\mathrm{~T}) \mathrm{mm}^{2}$ and a length of $240 \mathrm{~mm}$.

The criteria used to describe the load-displacement curve obtained are (figure $3 b$ ):

- one stiffness criterion, $\mathrm{P}_{\mathrm{f}}$, calculated from the initial linear part;

- one strength criterion, $\sigma_{f}$, the maximum stress before cracking, where $\mathrm{d}_{\mathrm{f}}$ is the associated displacement;

- one energetic criterion, $\mathrm{G}_{\mathrm{f}}$, which is calculated from the area below the complete load-displacement curve.

\subsection{Summary of tests and mechanical criteria measured}

\begin{tabular}{cccccc}
\hline test & $\begin{array}{c}\text { temperature } \\
\text { range }\left({ }^{\circ} \mathrm{C}\right)\end{array}$ & $\begin{array}{c}\text { number of } \\
\text { wood species } \\
\text { tested }\end{array}$ & $\begin{array}{c}\text { maximum } \\
\text { strain }\end{array}$ & $\begin{array}{c}\text { strain } \\
\text { rate s}^{-1}\end{array}$ & criteria $\mathrm{C}$ \\
\hline $\begin{array}{c}\text { radial } \\
\text { compression } \\
\begin{array}{c}\text { radial } \\
\text { shearing }\end{array}\end{array}$ & 0 to 99 & 10 & $23 \%$ & $28 \times 10^{-5}$ & $\begin{array}{c}\mathrm{E}_{\mathrm{R}}, \sigma_{\mathrm{y}}, \varepsilon_{\mathrm{y}}, \\
\mathrm{W}_{20 \%}\end{array}$ \\
$\begin{array}{c}\text { fracture } \\
25 \text { to } 80\end{array}$ & 10 & $16.7^{\circ}$ & $5 \times 10^{-3}$ & $\mathrm{G}_{\mathrm{R}}, \tau_{\mathrm{R}}, \gamma_{\mathrm{R}}, \mathrm{W}_{4.6}$ \\
\hline
\end{tabular}

Generally speaking, $\mathrm{C}$ will represent any criteria.

\subsection{Processing of rough data}

Since displacement is measured between the fixed crosshead and the moving platen, strain is a superposition of the real strain of specimens and the elastic deformation of the frame. Compression tests without wood specimen lead to the rigidity of the frame at each temperature. So elastic deformation of frame can be calculated and 


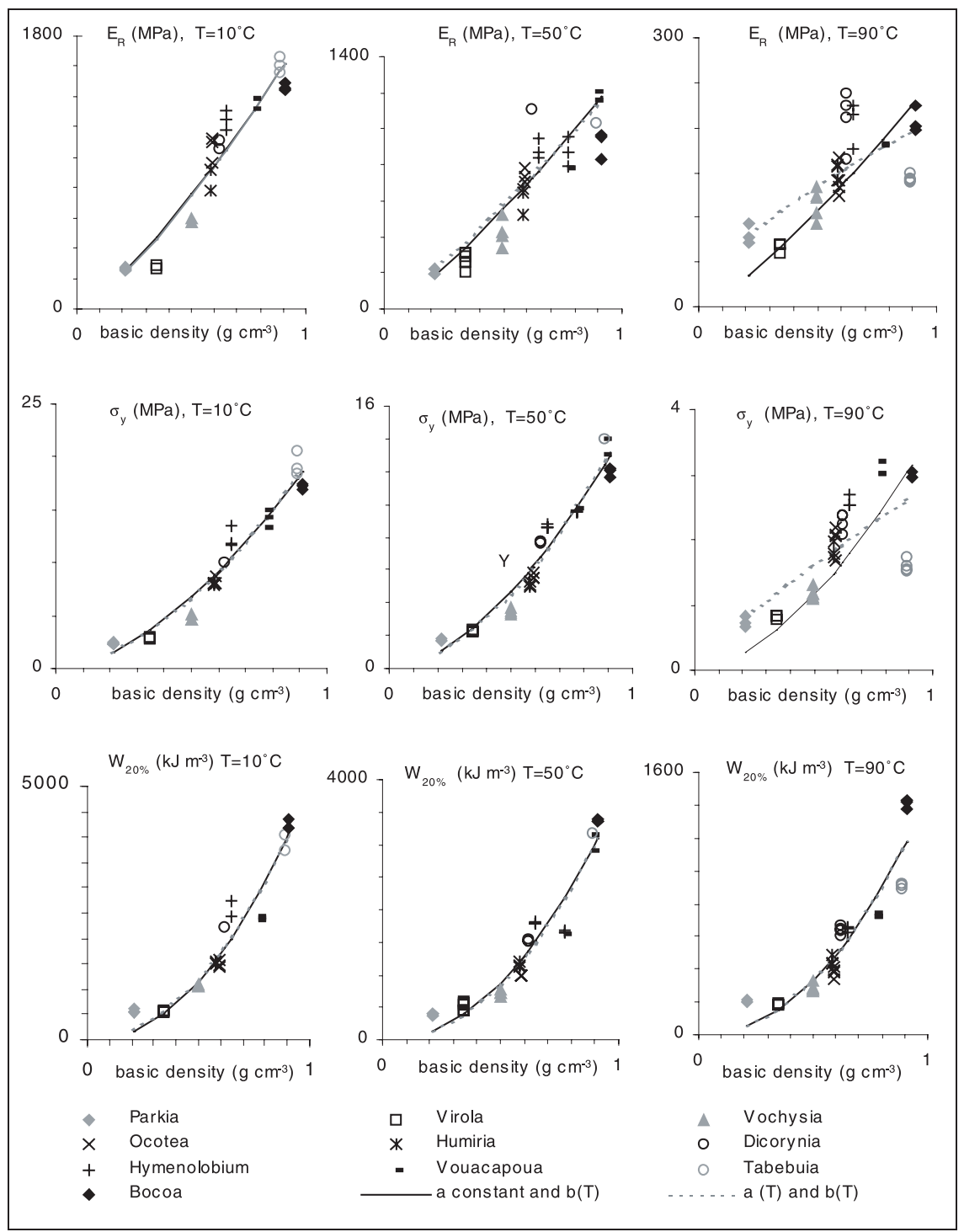

Figure 5. Evolution of mechanical criteria from compression test $\left(\mathrm{E}_{\mathrm{R}}, \sigma_{\mathrm{y}}\right.$ and $\left.\mathrm{W}_{20 \%}\right)$ respect to basic density for three temperatures. Solid lines represent theoretical laws.

subtracted from the total displacement in order to calculate the specimen displacement.

\section{RESULTS AND ANALYSIS}

\subsection{Influence of species}

Only deformation criteria $\left(\varepsilon_{\mathrm{y}}, \gamma_{\mathrm{R}}\right.$ and $\left.\mathrm{d}_{\mathrm{f}}\right)$ are slightly dependent on basic density. Otherwise, we observed a strong correlation between mechanical criteria and basic density. An illustration of the evolution of every mechanical criteria respect to basic density at one temperature is given in figure 4 .

In order to find a model which could represent the relation between mechanical criteria and basic density, we first focus our attention on mechanical criteria from radial compression tests. As temperature range is larger in compression tests, we assume that a model which would be relevant for compression criteria, could be applied to shearing and fracture criteria.
As shown by Guitard [5], the relation between criteria and basic density may be expressed in a general way by: $\mathrm{C}=\beta \times x^{\alpha}$. Here $\mathrm{C}$ is any mechanical criteria from compression test $\left(\mathrm{E}_{\mathrm{R}}, \sigma_{\mathrm{y}}\right.$ and $\left.\mathrm{W}_{20 \%}\right)$ and $x$ is the basic density. The parameters $\alpha$ and $\beta$ depend on wood species, but the question concerns the dependence between $\alpha, \beta$ and temperature. We tried two solutions to fit the model on experimental data:

- case 1: $\alpha$ and $\beta$ both depend on temperature;

- case 2: $\alpha$ is constant and $\beta$ depends on temperature.

It seems that these two solutions are not very different (figure 5). Comparison between determination coefficients calculated using case 1 and case 2 (table II) leads to the conclusion that both solutions are relevant. In order to get the simplest expression of the model, case 2 ( $\alpha$ constant and $\beta$ dependant on temperature) is chosen.

The power law presented previously is used to model the relation between criteria from shearing test $\left(\mathrm{G}_{\mathrm{R}}, \tau_{\mathrm{R}}\right.$ and $\left.\mathrm{W}_{4.6^{\circ}}\right)$, 
Table II. Values of the parameters in case 1 and case 2 calculated for three criteria $\left(\mathrm{E}_{\mathrm{R}}, \sigma_{\mathrm{y}}\right.$ and $\left.\mathrm{W}_{20 \%}\right)$. $\mathrm{R}^{2}$ is the determination coefficient.

\begin{tabular}{|c|c|c|c|c|c|c|c|c|c|c|c|c|}
\hline $\mathrm{T}\left({ }^{\circ} \mathrm{C}\right)$ & \multicolumn{2}{|c|}{$\mathrm{E}_{\mathrm{R}}($ case 1$)$} & \multicolumn{2}{|c|}{$\mathrm{E}_{\mathrm{R}}($ case 2$)$} & \multicolumn{2}{|c|}{$\sigma_{\mathrm{y}}($ case 1$)$} & \multicolumn{2}{|c|}{$\sigma_{\mathrm{y}}($ case 2$)$} & \multicolumn{2}{|c|}{$\mathrm{W}_{20 \%}($ case 1$)$} & \multicolumn{2}{|c|}{$\mathrm{W}_{20 \%}($ case 2$)$} \\
\hline & $\alpha$ & $\beta$ & $\alpha$ & $\beta$ & $\alpha$ & $\beta$ & $\alpha$ & $\beta$ & $\alpha$ & $\beta$ & $\alpha$ & $\beta$ \\
\hline 0 & 1.39 & 1971 & 1.28 & 1905 & 1.82 & 24.0 & 1.70 & 23,3 & 2,14 & 5207 & 2.13 & 5201 \\
\hline 5 & 1.29 & 1830 & & 1823 & 1.77 & 23.1 & & 22,8 & 2,15 & 5216 & & 5164 \\
\hline 10 & 1.28 & 1018 & & 1018 & 1.76 & 22.2 & & 21,9 & 2,09 & 4990 & & 5002 \\
\hline 15 & 1.32 & 1813 & & 1793 & 1.75 & 21.5 & & 21,3 & 2,08 & 4811 & & 4827 \\
\hline 20 & 1.39 & 1807 & & 1744 & 1.76 & 21.2 & & 20,9 & 2,08 & 4718 & & 4730 \\
\hline 25 & 1.24 & 1728 & & 1752 & 1.73 & 20.7 & & 20,6 & 2,09 & 4899 & & 4913 \\
\hline 30 & 1.19 & 1611 & & 1657 & 1.67 & 19.6 & & 19.8 & 2.07 & 4710 & & 4734 \\
\hline 35 & 1.29 & 1686 & & 1680 & 1.77 & 19.3 & & 19.0 & 2.12 & 4497 & & 4496 \\
\hline 40 & 1.22 & 1536 & & 1563 & 1.69 & 17.9 & & 18.0 & 2.09 & 4322 & & 4333 \\
\hline 45 & 1.27 & 1452 & & 1454 & 1.71 & 16.5 & & 16.5 & 2.11 & 4021 & & 4022 \\
\hline 50 & 1.17 & 1281 & & 1328 & 1.79 & 15.6 & & 15.2 & 2.21 & 3811 & & 3774 \\
\hline 55 & 1.19 & 1146 & & 1175 & 1.69 & 13.4 & & 13.4 & 2.22 & 3569 & & 3531 \\
\hline 60 & 1.49 & 1096 & & 1035 & 1.63 & 11.6 & & 11.9 & 2.25 & 3286 & & 3243 \\
\hline 65 & 1.60 & 912 & & 833 & 1.36 & 8.5 & & 9.4 & 2.23 & 2858 & & 2821 \\
\hline 70 & 1.31 & 611 & & 606 & 1.26 & 6.9 & & 7.9 & 2.25 & 2557 & & 2517 \\
\hline 75 & 0.82 & 366 & & 424 & 1.11 & 5.5 & & 6.4 & 2.23 & 2201 & & 2175 \\
\hline 80 & 0.89 & 311 & & 351 & 1.06 & 4.5 & & 5.4 & 2.24 & 1932 & & 1908 \\
\hline 85 & 0.82 & 273 & & 319 & 0.96 & 3.6 & & 4.5 & 2.09 & 1613 & & 1614 \\
\hline 90 & 0.64 & 209 & & 259 & 0.85 & 2.9 & & 3.7 & 2.13 & 1446 & & 1441 \\
\hline 95 & 0.75 & 183 & & 217 & 0.88 & 2.6 & & 3.2 & 2.09 & 1264 & & 1263 \\
\hline 99 & 0.89 & 194 & & 220 & 1.00 & 2.6 & & 3.2 & 2.09 & 1204 & & 1200 \\
\hline $\mathrm{R}^{2}$ & \multicolumn{2}{|c|}{0.904} & \multicolumn{2}{|c|}{0.902} & \multicolumn{2}{|c|}{0.960} & \multicolumn{2}{|c|}{0.958} & \multicolumn{2}{|c|}{0.945} & \multicolumn{2}{|c|}{0.944} \\
\hline
\end{tabular}

Table III. Values of the parameters calculated for criteria from shearing and fracture tests. $\mathrm{R}^{2}$ is the determination coefficient.

\begin{tabular}{|c|c|c|c|c|c|c|c|c|c|c|c|c|}
\hline $\mathrm{T}\left({ }^{\circ} \mathrm{C}\right)$ & \multicolumn{2}{|c|}{$\mathrm{G}_{\mathrm{R}}$} & \multicolumn{2}{|c|}{$\tau_{R}$} & \multicolumn{2}{|c|}{$\mathrm{W}_{4.6^{\circ}}$} & \multicolumn{2}{|c|}{$\mathrm{P}_{\mathrm{f}}$} & \multicolumn{2}{|c|}{$\sigma_{\mathrm{f}}$} & \multicolumn{2}{|c|}{$G_{f}$} \\
\hline & $\alpha$ & $\beta$ & $\alpha$ & $\beta$ & $\alpha$ & $\beta$ & $\alpha$ & $\beta$ & $\alpha$ & $\beta$ & $\alpha$ & $\beta$ \\
\hline 25 & 1.05 & 75.2 & 1.35 & 6.6 & 1.10 & 211 & 0.64 & 745 & 0.67 & 11.0 & 0.42 & 417.2 \\
\hline 30 & & 74.0 & & 6.6 & & 204 & & 703 & & 10.4 & & 399.5 \\
\hline 35 & & 71.0 & & 6.4 & & 194 & & 687 & & 10.4 & & 403.4 \\
\hline 40 & & 67.6 & & 6.1 & & 186 & & 637 & & 10.1 & & 391.9 \\
\hline 45 & & 65.8 & & 5.8 & & 178 & & 601 & & 9.6 & & 424.6 \\
\hline 50 & & 62.3 & & 5.4 & & 165 & & 534 & & 9.2 & & 428.8 \\
\hline 55 & & 58.2 & & 4.8 & & 149 & & 474 & & 8.5 & & 412.0 \\
\hline 60 & & 52.4 & & 4.2 & & 131 & & 426 & & 7.9 & & 441.5 \\
\hline 65 & & 44.7 & & 3.6 & & 111 & & 368 & & 7.2 & & 461.4 \\
\hline 70 & & 35.2 & & 3.0 & & 89 & & 313 & & 6.3 & & 442.5 \\
\hline 75 & & 29.3 & & 2.6 & & 74 & & 254 & & 5.5 & & 445.7 \\
\hline 80 & & 24.1 & & 2.3 & & 62 & & 204 & & 4.7 & & 175.3 \\
\hline $\mathrm{R}^{2}$ & & & & & & & & & & & & \\
\hline
\end{tabular}

fracture test $\left(\mathrm{P}_{\mathrm{f}}, \sigma_{\mathrm{f}}\right.$ and $\left.\mathrm{G}_{\mathrm{f}}\right)$ and basic density. The parameters $\alpha$ and $\beta$ are calculated to adjust the theoretical law to experimental data (table III).

Correlation between $\mathrm{G}_{\mathrm{f}}$ and basic density is less strong than other criteria $\left(\mathrm{R}^{2}=0.351\right.$ whereas $\mathrm{R}^{2}$ is higher than 0.6 in other cases).

\subsection{Influence of temperature on mechanical criteria}

The curves representing the evolution of each mechanical criterion in function of temperature show the same typical relaxation pattern except for $\mathrm{G}_{\mathrm{f}}$. It is interesting to note that criteria representing deformation $\left(\varepsilon_{y}, \gamma_{R}\right.$ and $\left.d_{f}\right)$ increase with temperature whereas other criteria decrease. One wood species (Dicorynia) is chosen to give an illustration of this observation and mechanical criteria from the different tests are plotted as a function of temperature in figure 6.

The curves of $E_{R}, G_{R}, P_{f}, \sigma_{y}, \tau_{R}, \sigma_{R}, W_{20 \%}$ and $W_{4.6^{\circ}}$ in function of temperature are typical of a viscoelastic material [3]. Globally, each of these criteria varies in function of temperature in the same way. At low temperatures this type of criterion is roughly constant (glassy region), then it decreases drastically around $55^{\circ} \mathrm{C}$ (glassy transition), finally it tends to be again roughly constant (rubbery plateau). Nevertheless, it 


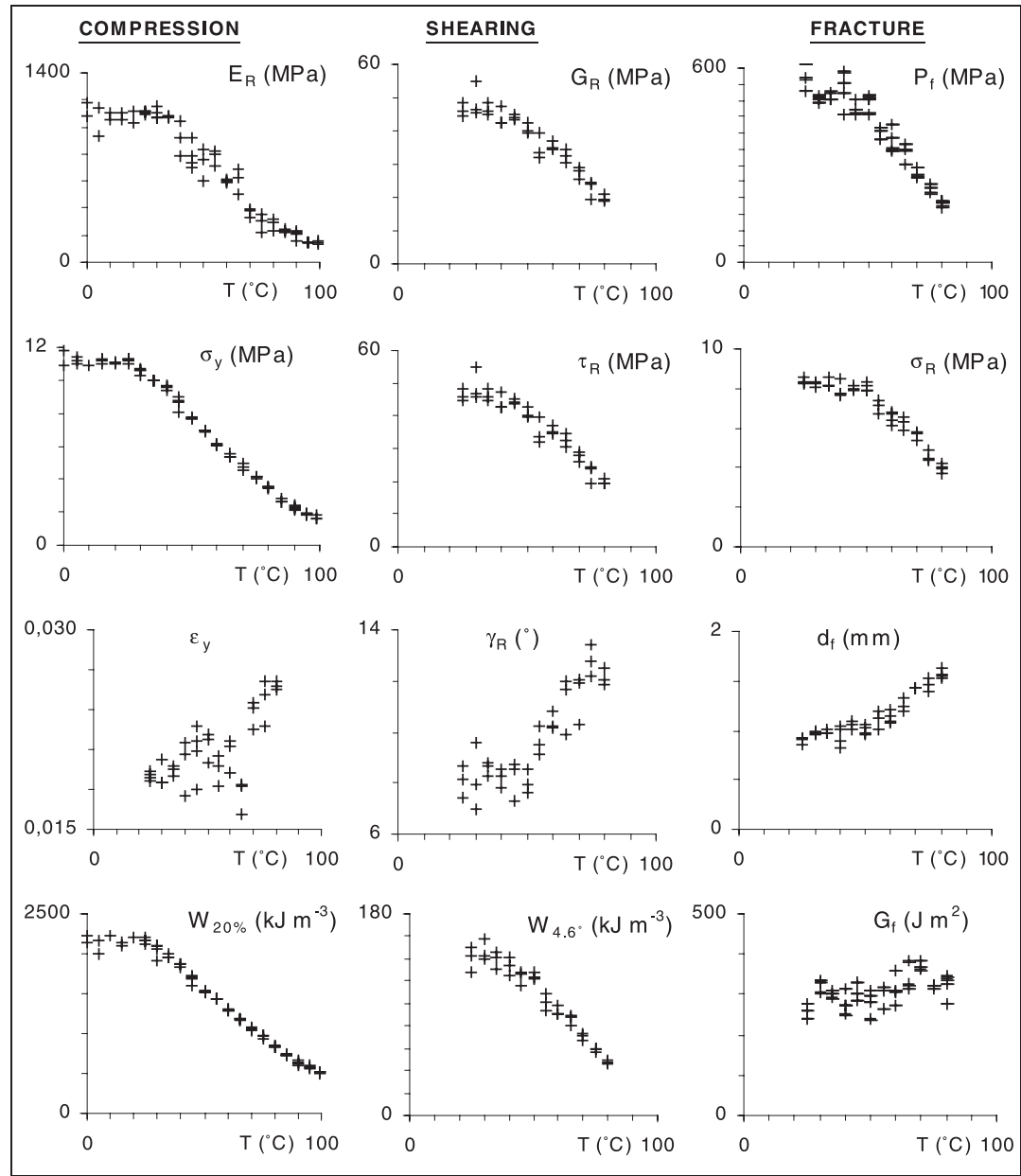

Figure 6. Evolution of the twelve mechanical criteria in function of temperature for one wood species (Dicorynia). Each cross represents one value of the three repetitions.

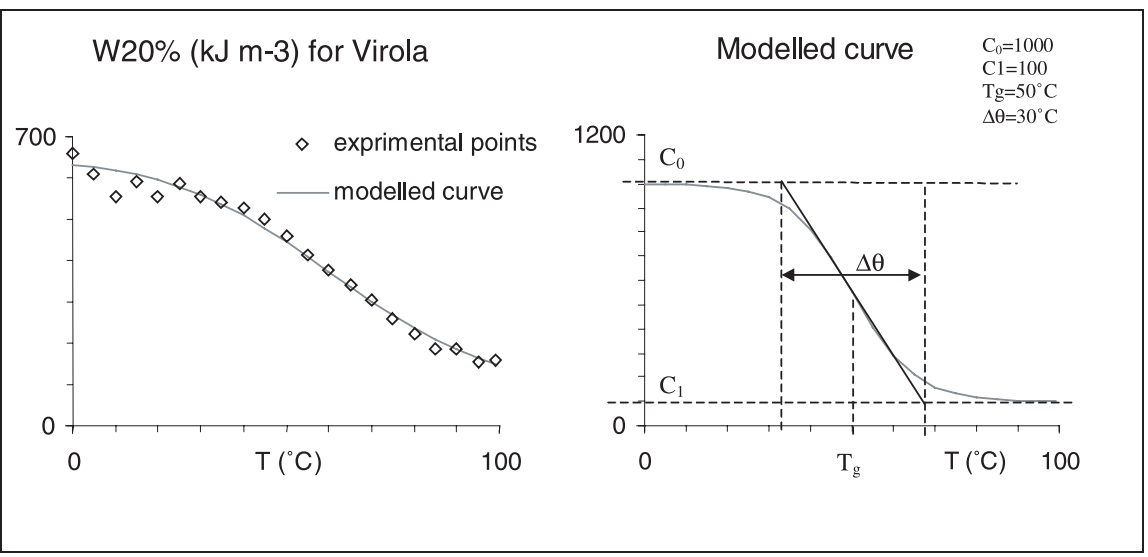

Figure 7. Illustration of the model of evolution of one criterion respect to temperature.

seems that the softening phenomenon is not completed at $80{ }^{\circ} \mathrm{C}$. Regarding the experimental conditions, the drastic change of mechanical properties can be brought about by the glassy transition of one of the polymeric constituent of wood: lignin $[4,9]$. Nevertheless, one should not forget that wood is a polymeric composite and so it presents a multitransition viscoelastic behaviour.
The fact that the energetic criterion $\mathrm{G}_{\mathrm{f}}$ from fracture test is not related to temperature is important for the prediction of crack propagation. In simulation of crack propagation, $G_{f}$ can be taken as constant.

In order to present the effect of temperature on every criteria, it was suggested to measure softening temperature on graphs. The curves of criterion in function of temperature were 


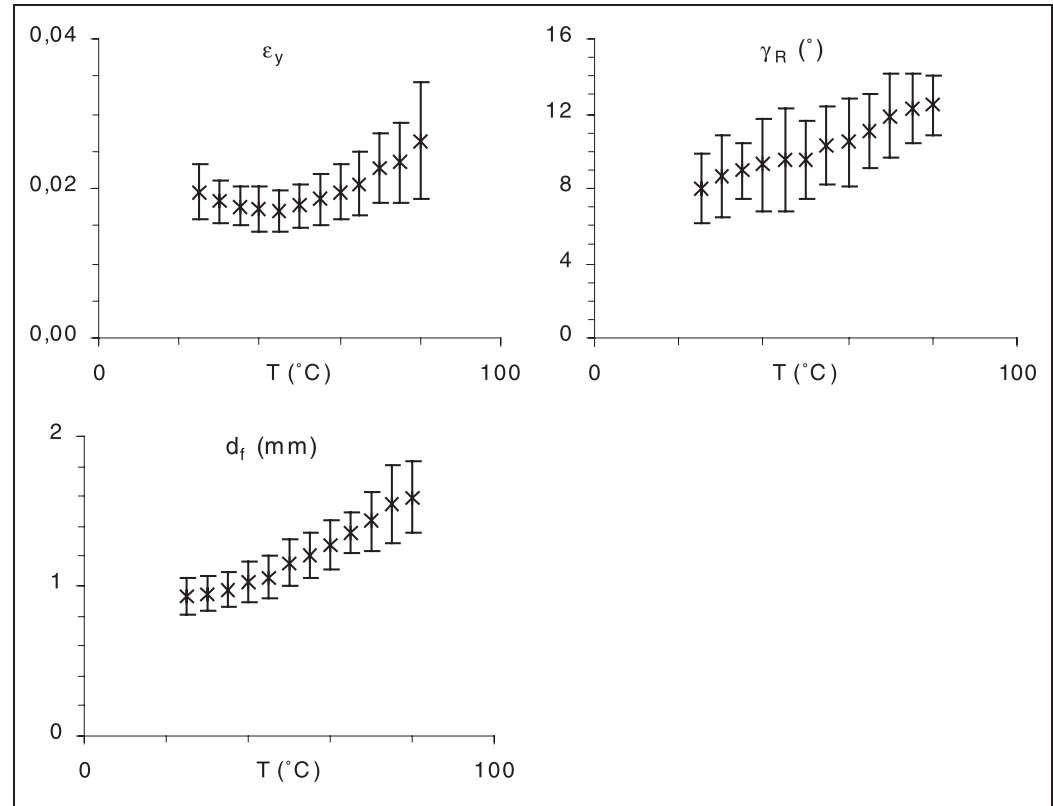

Figure 8. Evolution of $\varepsilon_{\mathrm{y}}, \gamma_{\mathrm{R}}\left(^{\circ}\right)$ and $\mathrm{d}_{\mathrm{f}}$ $(\mathrm{mm})$ in function of temperature. Crosses represent the average value on ten wood species, vertical lines show the standard deviation.

Table IV. Values of the softening parameters calculated from the evolution of three mechanical criteria from radial compression tests $\left(\mathrm{E}_{\mathrm{R}}, \sigma_{\mathrm{y}}\right.$ and $\mathrm{W}_{20 \%}$ ) in function of temperature for each species.

\begin{tabular}{lccccccccc}
\hline & \multicolumn{3}{c}{$\mathrm{E}_{\mathrm{R}}$} & \multicolumn{2}{c}{$\sigma_{\mathrm{y}}$} & \multicolumn{2}{c}{$\mathrm{W}_{20 \%}$} \\
\hline Species & $\mathrm{T}_{\mathrm{g}}\left({ }^{\circ} \mathrm{C}\right)$ & $\Delta \theta\left({ }^{\circ} \mathrm{C}\right)$ & $\mathrm{C}_{0} / \mathrm{C}_{1}$ & $\mathrm{~T}_{\mathrm{g}}\left({ }^{\circ} \mathrm{C}\right)$ & $\Delta \theta\left({ }^{\circ} \mathrm{C}\right)$ & $\mathrm{C}_{0} / \mathrm{C}_{1}$ & $\mathrm{~T}_{\mathrm{g}}\left({ }^{\circ} \mathrm{C}\right)$ & $\Delta \theta\left({ }^{\circ} \mathrm{C}\right)$ & $\mathrm{C}_{0} / \mathrm{C}_{1}$ \\
\hline Parkia & 69 & 73.1 & 10.3 & 61 & 85.4 & 10.4 & 55 & 98.4 & 8.7 \\
Virola & 62 & 66.0 & 15.0 & 64 & 68.4 & 9.7 & 61 & 79.3 & 8.5 \\
Vochysia & 53 & 37.1 & 7.4 & 56 & 68.8 & 9.9 & 54 & 60.9 & 5.7 \\
Ocotea & 57 & 48.6 & 14.5 & 57 & 78.8 & 10.2 & 58 & 82.2 & 9.2 \\
Humiria & 58 & 41.5 & 8.3 & 46 & 91.1 & 12.8 & 60 & 65.9 & 6.2 \\
Dicorynia & 60 & 50.4 & 10.9 & 60 & 64.1 & 13.7 & 59 & 63.1 & 5.4 \\
Hymenolobium & 60 & 45.0 & 9.7 & 58 & 49.4 & 6.9 & 57 & 49.4 & 5.2 \\
Vouacapoua & 57 & 40.8 & 9.0 & 57 & 74.3 & 13.9 & 56 & 65.2 & 4.7 \\
Tabebuia & 57 & 40.0 & 16.6 & 57 & 53.4 & 31.0 & 65 & 59.5 & 11.7 \\
Bocoa & 54 & 52.8 & 13.5 & 54 & 63.8 & 15.7 & 64 & 77.9 & 7.5 \\
\hline
\end{tabular}

not smooth enough to allow a precise measure of softening temperature of relaxation phenomena. The following mathematical expression was used to describe the curves:

$$
\mathrm{C}=\frac{\mathrm{C}_{0}+\mathrm{C}_{1}}{2}-\frac{\mathrm{C}_{0}-\mathrm{C}_{1}}{2} \tanh \left(2 \frac{\mathrm{T}-\mathrm{T}_{\mathrm{g}}}{\Delta \theta}\right)
$$

where $\mathrm{C}$ is the criterion measured (except $\mathrm{G}_{\mathrm{f}}$ ), $\mathrm{C}_{0}$ and $\mathrm{C}_{1}$ the limits at low and high temperature, $\mathrm{T}$ the temperature, $\mathrm{T}_{\mathrm{g}}$ the temperature at the inflexion point and $\Delta \theta$ the variation of temperature required for $\mathrm{C}$ to decrease from $\mathrm{C}_{1}$ to $\mathrm{C}_{0}$ (figure 7).

The three main parameters calculated from this expression are $T_{g}$, which corresponds to the softening temperature, $\Delta \theta$ which gives an illustration of the spread of the relaxation phenomenon and the ratio $C_{1}$ over $C_{0}$ which gives the amplitude of the phenomenon. Values of these softening parameters are given in table $I V$, table $V$ and table $V I$ for each mechanical parameters. Table VII gives an average value of these parameters for each mechanical criteria $\mathrm{C}$.

Deformation criteria $\left(\varepsilon_{\mathrm{y}}, \gamma_{\mathrm{R}}\right.$ and $\left.\mathrm{d}_{\mathrm{f}}\right)$ are studied separately. It was shown previously that they are almost independent of wood species, so we can work on the average value on the ten species. Figure 8 presents the evolution of average values of $\varepsilon_{\mathrm{y}}, \gamma_{\mathrm{R}}$ and $\mathrm{d}_{\mathrm{f}}$ in function of temperature.

Deformation criterion from compression test $\left(\varepsilon_{\mathrm{y}}\right)$, first decreases slightly from $1.9 \%$ to $1.7 \%$ between 25 and $45^{\circ} \mathrm{C}$ and then increases until $2.6 \%$. The value of $\gamma_{R}$ increases from $8^{\circ}$ to $12.5^{\circ}$ while temperature increases from 25 to $80^{\circ} \mathrm{C}$, demonstrating that wood is more ductile at high temperature. The evolution of $d_{f}$ is similar: $d_{f}$ increases from 1 to $1.8 \mathrm{~mm}$. A model can be applied to the evolution of $\gamma_{R}$ and $d_{f}$ using the following theoretical law:

$$
\mathrm{C}=\frac{\mathrm{C}_{0}+\mathrm{C}_{1}}{2}-\frac{\mathrm{C}_{0}-\mathrm{C}_{1}}{2} \tanh \left(2 \frac{\mathrm{T}-\mathrm{T}_{\mathrm{g}}}{\Delta \theta}\right)
$$

where the parameters are the same as previously. 
Table V. Values of the softening parameters calculated from the evolution of three mechanical criteria from rolling shear tests $\left(G_{R}\right.$, $\tau_{\mathrm{R}}$ and $\mathrm{W}_{4.6^{\circ}}$ ) in function of temperature for each species.

\begin{tabular}{|c|c|c|c|c|c|c|c|c|c|}
\hline \multirow[b]{2}{*}{ Species } & \multicolumn{3}{|c|}{$\mathrm{G}_{\mathrm{R}}$} & \multicolumn{3}{|c|}{$\tau_{R}$} & \multicolumn{3}{|c|}{$\mathrm{W}_{4.6^{\circ}}$} \\
\hline & $\mathrm{T}_{\mathrm{g}}\left({ }^{\circ} \mathrm{C}\right)$ & $\Delta \theta\left({ }^{\circ} \mathrm{C}\right)$ & $\mathrm{C}_{0} / \mathrm{C}_{1}$ & $\mathrm{~T}_{\mathrm{g}}\left({ }^{\circ} \mathrm{C}\right)$ & $\Delta \theta\left({ }^{\circ} \mathrm{C}\right)$ & $\mathrm{C}_{0} / \mathrm{C}_{1}$ & $\mathrm{~T}_{\mathrm{g}}\left({ }^{\circ} \mathrm{C}\right)$ & $\Delta \theta\left({ }^{\circ} \mathrm{C}\right)$ & $\mathrm{C}_{0} / \mathrm{C}_{1}$ \\
\hline Parkia & 62 & 37.5 & 3.4 & 62 & 48.1 & 2.6 & 62 & 47.5 & 4.1 \\
\hline Virola & 64 & 38.7 & 4.4 & 58 & 43.6 & 2.9 & 60 & 46.7 & 4.4 \\
\hline Vochysia & 59 & 48.4 & 7.1 & 53 & 43.4 & 2.7 & 51 & 57.6 & 7.0 \\
\hline Ocotea & 58 & 56 & 4.0 & 56 & 47.7 & 3.5 & 54 & 61 & 5.8 \\
\hline Humiria & 61 & 36.2 & 4.3 & 58 & 48.7 & 4.4 & 60 & 42.1 & 4.5 \\
\hline Dicorynia & 63 & 45.8 & 3.6 & 57 & 46.7 & 3.7 & 61 & 42.7 & 4.6 \\
\hline Hymenolobium & 62 & 36.6 & 4.7 & 58 & 40.8 & 4.0 & 59 & 45.2 & 5.6 \\
\hline Vouacapoua & 61 & 43.6 & 4.1 & 58 & 46.2 & 3.7 & 58 & 44.3 & 4.7 \\
\hline Tabebuia & 60 & 33.6 & 4.9 & 59 & 30.6 & 3.9 & 58 & 34.6 & 5.6 \\
\hline Bocoa & 65 & 27.1 & 4.7 & 59 & 32.2 & 3.3 & 64 & 30.5 & 4.4 \\
\hline
\end{tabular}

Table VI. Values of the softening parameters calculated from the evolution of two mechanical criteria from fracture toughness tests $\left(\mathrm{P}_{\mathrm{f}}\right.$ and $\left.\sigma_{\mathrm{f}}\right)$ in function of temperature for each species.

\begin{tabular}{lcccccc}
\hline & \multicolumn{3}{c}{$\mathrm{Pf}$} & \multicolumn{3}{c}{$\sigma_{\mathrm{f}}$} \\
\hline Species & $\mathrm{T}_{\mathrm{g}}\left({ }^{\circ} \mathrm{C}\right)$ & $\Delta \theta\left({ }^{\circ} \mathrm{C}\right)$ & $\mathrm{C}_{0} / \mathrm{C}_{1}$ & $\mathrm{~T}_{\mathrm{g}}\left({ }^{\circ} \mathrm{C}\right)$ & $\Delta \theta\left({ }^{\circ} \mathrm{C}\right)$ & $\mathrm{C}_{0} / \mathrm{C}_{1}$ \\
\hline Parkia & 60 & 43.5 & 3.4 & 60 & 39.3 & 2.3 \\
Virola & 58 & 61.7 & 2.3 & 61 & 45.9 & 1.7 \\
Vochysia & 54 & 44.3 & 3.5 & 59 & 48.4 & 3.0 \\
Ocotea & 54 & 39.9 & 3.3 & 61 & 43.6 & 2.8 \\
Humiria & 54 & 37.8 & 5.0 & 57 & 44.5 & 4.0 \\
Dicorynia & 62 & 57.9 & 6.2 & 63 & 37.1 & 2.3 \\
Hymenolobium & 54 & 54 & 8.6 & 63 & 51 & 3.0 \\
Vouacapoua & 61 & 47.8 & 7.5 & 61 & 56.5 & 2.6 \\
Tabebuia & 56 & 45.9 & 10.7 & 59 & 47.2 & 4.8 \\
Bocoa & 58 & 47.5 & 6.6 & 60 & 38.8 & 2.8 \\
\hline
\end{tabular}

Table VIII gives the values of the parameters calculated from this model for $\gamma_{R}$ and $d_{f}$. These parameters are in the same range as those calculated from others criteria.

Values of $T_{g}$ calculated from the evolution of each criterion respect to temperature are quite close. Nevertheless, two criteria have higher values for $T_{g}: G_{R}$ and $\sigma_{f}$. This difference can be accounted for by a superposition of tension and compression strain during the shearing and fracture tests. Both $\Delta \theta$ and $\mathrm{C}_{0} / \mathrm{C}_{1}$ present an important variation from criterion to criterion.

The outcome of these observations is that softening temperature seems to be independent of mechanical criteria studied, whereas spread and amplitude of the softening behaviour are affected by them. These observations lead to the focus on one mechanical test to study the softening behaviour and one criterion. Compression test and $\mathrm{E}_{\mathrm{R}}$ are selected.

\subsection{Detailed study of one mechanical criterion: $E_{R}$ from compression test}

To go further in the investigations, we studied the influence of species on one criterion: $\mathrm{E}_{\mathrm{R}}$ measured from compression tests. Figure 9 presents the evolution of $\mathrm{E}_{\mathrm{R}}$ in function of temperature for each wood species.
Table VII. Average values of the parameters for each mechanical criteria $\mathrm{C}$, the mean is calculated on the 10 species, "sd" represents the standard deviation.

\begin{tabular}{lccccccc}
\hline Test & $\mathrm{C}$ & $\mathrm{Tg}\left({ }^{\circ} \mathrm{C}\right)$ & $\mathrm{sd}$ & $\Delta \theta\left({ }^{\circ} \mathrm{C}\right)$ & $\mathrm{sd}$ & $\mathrm{C}_{0} / \mathrm{C}_{1}$ & $\mathrm{sd}$ \\
\hline Radial & $\mathrm{E}_{\mathrm{R}}$ & $\mathbf{5 8 . 4}$ & 3.47 & $\mathbf{4 0 . 3}$ & 7.50 & $\mathbf{7 . 5}$ & 2.35 \\
compression & $\sigma_{\mathrm{y}}$ & $\mathbf{5 7 . 4}$ & 2.91 & $\mathbf{5 2 . 4}$ & 9.66 & $\mathbf{6 . 1}$ & 2.00 \\
& $\mathrm{~W}_{20 \%}$ & $\mathbf{5 7 . 8}$ & 4.34 & $\mathbf{6 0 . 2}$ & 5.55 & $\mathbf{4 . 9}$ & 0.87 \\
& & & & & & \\
Radial & $\mathrm{G}_{\mathrm{R}}$ & $\mathbf{6 1 . 5}$ & 2.17 & $\mathbf{4 0 . 3}$ & 8.26 & $\mathbf{4 . 5}$ & 1.02 \\
shearing & $\tau_{\mathrm{R}}$ & $\mathbf{5 7 . 8}$ & 2.30 & $\mathbf{4 2 . 8}$ & 6.48 & $\mathbf{3 . 5}$ & 0.64 \\
& $\mathrm{~W}_{4,6^{\circ}}$ & $\mathbf{5 8 . 7}$ & 3.80 & $\mathbf{4 5 . 2}$ & 9.16 & $\mathbf{5 . 0}$ & 0.97 \\
& & & & & & & \\
Fracture & $\mathrm{P}_{\mathrm{f}}$ & $\mathbf{5 7 . 1}$ & 3.14 & $\mathbf{4 8 . 0}$ & 7.69 & $\mathbf{5 . 7}$ & 2.72 \\
& $\sigma_{\mathrm{f}}$ & $\mathbf{6 0 . 4}$ & 1.84 & $\mathbf{4 5 . 2}$ & 5.96 & $\mathbf{2 . 9}$ & 0.86 \\
\hline
\end{tabular}

Table VIII. Values of the softening parameters calculated from the evolution of two deformation criteria $\gamma_{\mathrm{R}}$ and $\mathrm{d}_{\mathrm{f}}$.

\begin{tabular}{cccccc}
\hline \multicolumn{3}{c}{$\gamma \mathrm{R}$} & & \multicolumn{3}{c}{$\mathrm{df}$} \\
\hline $\mathrm{T}_{\mathrm{g}}\left({ }^{\circ} \mathrm{C}\right)$ & $\Delta \theta\left({ }^{\circ} \mathrm{C}\right)$ & $\mathrm{C}_{0} / \mathrm{C}_{1}$ & $\mathrm{~T}_{\mathrm{g}}\left({ }^{\circ} \mathrm{C}\right)$ & $\Delta \theta\left({ }^{\circ} \mathrm{C}\right)$ & $\mathrm{C}_{0} / \mathrm{C}_{1}$ \\
\hline 62 & 57 & 1.7 & 60 & 38 & 1.8 \\
\hline
\end{tabular}

Examining the curves $E_{R}$ in function of temperature, it seems that many species (especially Humiria and Bocoa) have a first inflexion point around $5{ }^{\circ} \mathrm{C}$. This phenomenon may be accounted for by a secondary transition of lignin or by a glassy transition of hemicelluloses.

Applying the mathematical law presented in the previous paragraph to the evolution of $E_{R}$ with respect to temperature, three softening parameters were calculated for each species: $\mathrm{T}_{\mathrm{g}}, \mathrm{C}_{0} / \mathrm{C}_{1}$ and $\Delta \theta$. From table $I V$, we observed that the softening temperature, $T_{g}$, varies from one wood species to the other between $54^{\circ} \mathrm{C}$ and $65^{\circ} \mathrm{C}$. The glassy transition seems to depend on the wood species studied. The following question raises: what could be the structural parameters which handle the relaxation phenomenon? 


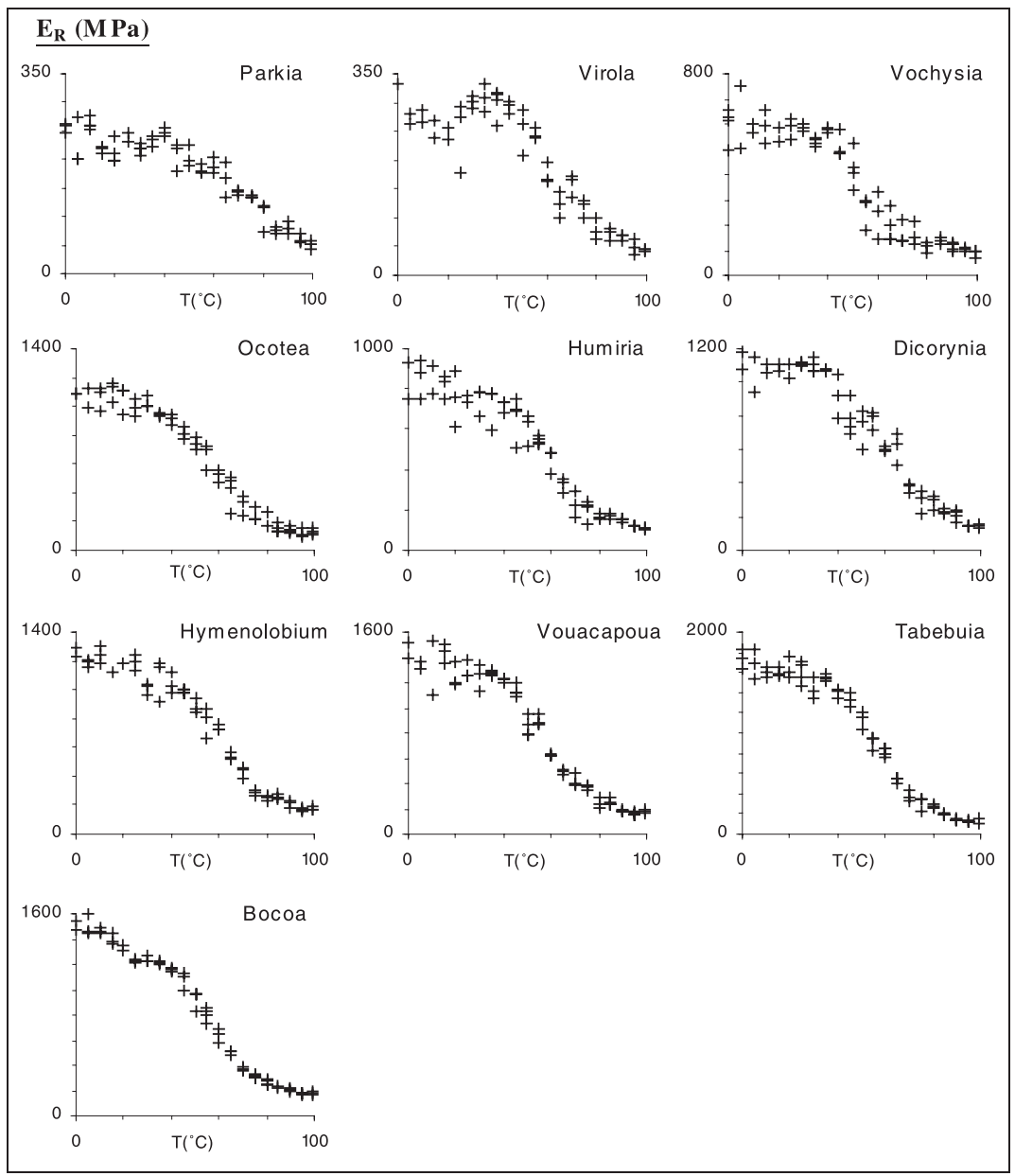

Figure 9. Evolution of $E_{R}(\mathrm{MPa})$ from compression test in function of temperature for each wood species. Single cross represents one value of the three repetitions.

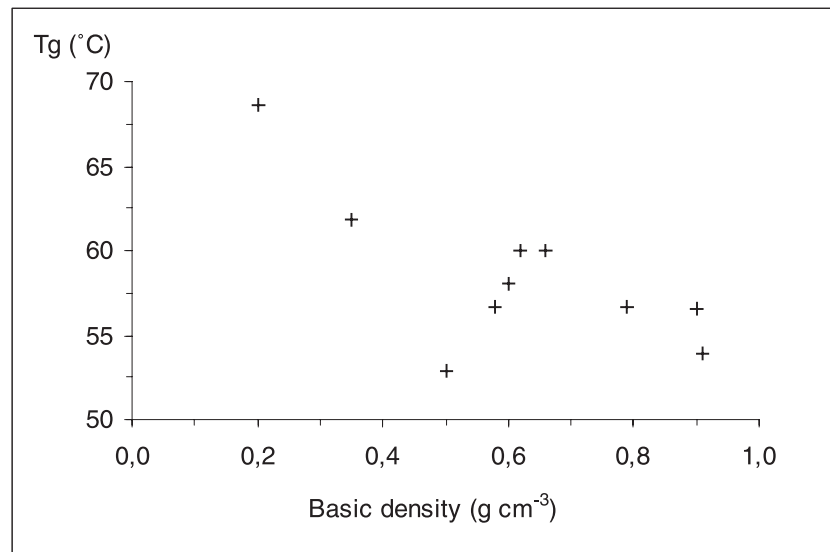

Figure 10. Evolution of $T_{g}$ in function of basic density.

First it is suggested that basic density could explain the differences between wood species. Referring to the plot of $\mathrm{T}_{\mathrm{g}}$ as a function of basic density (figure 10), it appears that softening occurs at higher temperature for species with lower basic density. For basic density over $0.5 \mathrm{~g} \mathrm{~cm}^{-3}$, this parameter seems not to influence $\mathrm{T}_{\mathrm{g}}$.

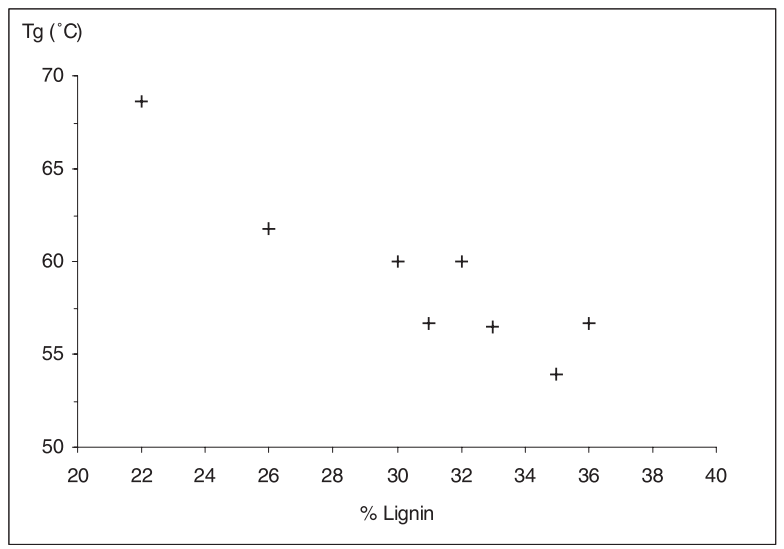

Figure 11. Evolution of $\mathrm{T}_{\mathrm{g}}$ in function of lignin percentage.

Nevertheless, we wonder if the basic density is the relevant parameter to explain differences between softening behaviour of wood species. It can be hypothesised that differences between species may be ascribed to chemical composition of wood. Looking at a data-base from CIRAD, we know the lignin composition of eight of the ten Guyanese species tested. 
Referring to figure $11, \mathrm{~T}_{\mathrm{g}}$ and the percentage of lignin seem correlated.

Unfortunately, it appears that the choice of these wood species is not neutral. Actually, it exists a relation between basic density and lignin percentage of these species, so we can not conclude about influence of chemical composition on softening behaviour.

\section{CONCLUSION}

These mechanical tests have provided numerous data about transverse mechanical behaviour of ten tropical species under water-saturated conditions. Mechanical properties were studied through three kinds of test: radial compression, transverse shearing and transverse fracture toughness. Influence of both basic density and temperature was highlighted.

All mechanical criteria, except deformation criteria depend on wood species. The relation between these criteria $(\mathrm{C})$ and basic density can be expressed by the following power law: $\mathrm{C}=\beta \times x^{\alpha}$. The parameter $\alpha$ varies between 1.3 to 2.1 for compression, 1 to 1.3 for shearing and 0.4 to 0.7 for fracture toughness, according to criteria inside the test.

The influence of temperature on transverse properties of water-saturated samples of tropical wood was clearly noticed. Softening phenomena were observed on mainly all the criteria except for deformation criteria and $\mathrm{G}_{\mathrm{f}}$. This last remark is coherent with classical analysis of crack propagation. Deformation criteria increase with temperature which shows that wood is more ductile when temperature increases. Other criteria depend on temperature following law like:

$$
\mathrm{C}=\frac{\mathrm{C}_{1}+\mathrm{C}_{0}}{2}-\frac{\mathrm{C}_{1}-\mathrm{C}_{0}}{2} \tanh \left(2 \frac{\mathrm{T}-\mathrm{T}_{\mathrm{g}}}{\Delta \theta}\right) .
$$

The softening temperature, $\mathrm{T}_{\mathrm{g}}$, corresponding to the inflexion point of the curve, is varying between $54{ }^{\circ} \mathrm{C}$ and $65^{\circ} \mathrm{C}$, depending more on wood species than on mechanical criteria.

\section{REFERENCES}

[1] Baldwin R.F., Plywood and veneer-based products, manufacturing practices, Miller Freeman Books Inc, USA, 1995.

[2] Beauchêne J., Évolution du comportement mécanique du bois vert avec la température. Application à l'étude du déroulage et du tranchage de quelques bois guyanais, Thèse de l'Engref en Sciences du bois, 1996.

[3] Gerhards C.C., Effect of moisture content and temperature on the mechanical properties of woods: an analysis of immediate effects, Wood Fiber 14 (1982) 4-36.

[4] Goring D.A.I., Thermal softening of lignin, hemicellulose and cellulose, Pulp Pap. Mag. Can. 64 (1963) 517-527.

[5] Guitard D., Mécanique du matériau bois et composites, Cepadues édition, 1987.

[6] Gustafsson P.J., Eurocode 5 draft design criterion for notched beams, 1991.

[7] Koch P., Machining, in: Utilization of hardwoods growing on southern pine sites, U.S. Dep. Agri. For. Ser. (Ed.), 1985 pp. 1688-2281.

[8] Lutz J.F., Techniques for peeling, slicing and drying veneer, FPL Madison Report. 228 (1974).

[9] Salmen L., Viscoelastic properties of in situ lignin under watersaturated conditions, J. Mater. Sci. 19 (1984) 3090-3096.

[10] Thibaut B., Le processus de coupe du bois par déroulage, Thèse de Doctorat d'État, 1988. 